\title{
Game-Based Versus to Non-Game-Based: The Impact of Student Response Systems on Students'Achievements, Engagements and Test Anxieties
}

\author{
Zeynep TURAN ${ }^{1 *}$, Elif MERAL ${ }^{2}$ \\ ${ }^{1}$ Department of Computer Education and Instructional Technology, \\ Faculty of Education, Ataturk University \\ Erzurum/TURKEY \\ ${ }^{2}$ Department of Social Sciences Education, Faculty of Education, Ataturk University \\ Erzurum/TURKEY \\ e-mail:zeynepatauniv@hotmail.com,elif.meral@atauni.edu.tr
}

Received: July 2017

\begin{abstract}
The use of different tools in the field of education has become widespread with the developments in technology. Online student response systems are one of these tools. Online student response systems have been used for many years. In the last couple of years, game items have been added, and game-based online student response systems have started to be used. In this context, this study aims to find out the effects of online student response systems both with and without being based on games on the achievements, engagements, and test anxiety levels of students. The study group consists of 46 seventh grade students (Control, 23; Experimental, 23). This study was conducted by using a quasi-experimental design with pre-test and post-test groups. The topics in the "living democracy" chapter of social studies course were taught for four weeks by using the online student response system named Socrative for the control group and the online game-based student response system called Kahoot for the experimental group. The results of the study showed that game-based student response systems increase the achievement and engagement and decrease the test anxiety level when compared to non-game-based student response systems. In this direction, it may be suggested to use online game-based student response systems on different topics of social studies courses.
\end{abstract}

Keywords: student response system, game-based student response system, achievement, engagement, test anxiety.

* Corresponding Author 


\section{Introduction}

It is a fact that it is hard to ensure the continuity of the attention of the students and their engagements during lectures. In this direction, to ensure the continuity of the attention and engagements of the students, student response systems can be used. Because, the average attention periods of people are no more than 20 minutes and because of this the use of student response systems can be used to re-catch people's attention (Burns, 1985; Caldwell, 2007). Besides, Johnson and Lillis (2010) found out in the studies made with small laboratory groups each of which makes studies on different topics that student response systems increase the achievement and concentration of the students.

The use of student response systems has increased considerably over the past years, and the researchers have been adding an increasing attention on the effects of student response systems on learning and engagement (Aljaloud, Gromik, Billingsley, Kwan, 2015). Students response based technologies are named in different ways in the literature. These names are student response system (Wang, 2015), audience response system (Pettit, McCoy, Kinney, Schwartz, 2015), classroom response system (Kortemeyer, 2016), personal response system (Song, Oh, Glazewski, 2017) and lastly, clickers (Jones, Henderson, Sealover, 2009). In this study, Student Response System (SRS) is used to ensure integrity.

The existence of student response systems goes back to 1960s (Judson and Sawada, 2002). SRSs were firstly used in biology and chemistry education during the beginning of the 1970s (Bessler and Nisbet, 1971). The SRSs that were coined during the 1960s were evolved both regarding their forms and capabilities (Hunsu, Adesope, Bayly, 2016). Lately, web-based SRSs and SRSs that support mobile devices have become widelyused (Richardson, Dunn, McDonald, Oprescu, 2015). Besides, with the enhancements in technology, the use of personal devices during the classes was supported, and this situation decreased the costs of using SRSs in the classes (Aljaloud, Gromik, Billingsley, Kwan, 2015; Hunsu, Adesope, Bayly, 2016).

SRSs are very useful tools also regarding enabling teachers to give instant feedbacks to the students and evaluate their performance during the lectures (Aljaloud, Gromik, Billingsley, Kwan, 2015; Hunsu, Adesope, Bayly, 2016). Additionally, it is stated that the use of SRSs increases the interactions in the classroom and the attention of students related to learning (Hunsu, Adesope, Bayly, 2016). According to a study in the literature, both the students and the teachers have the same positive attitude towards SRSs. Besides, it is underlined in the same study that SRSs increase the achievements of students in the exams and provides the students with a more active classroom environment (Caldwell, 2007). Moreover, the educators accept the use of SRSs with an increasing rate to increase the engagement of the students (Bergtrom, 2006; Habel and Stubbs, 2014; Duncan, 2005; Fies and Marshall, 2006; Simpson and Oliver, 2007). In accordance with this, several studies claim that the success and performance of students in the lectures where SRSs are used is higher compared to the same factors in the lectures where SRSs are not used (Morling, McAuliffe, Cohen, DiLorenzo, 2008; Mula and Kavanagh, 2009; Poirier and Feldman, 2007). Besides, 
studies showed that reading a text improves information retention better when followed by a test rather than a second session of reading of the same text (Adesope and Nesbit, 2013; Roedriger and Karpicke, 2006).

Recently, Game-based Student Response Systems (GSRSs) started to appear. The main difference between GSRSs and non-game-based SRSs is the creation of energy and engagement by using gamification (Wang, 2015). Today, Kahoot is a widely used GSRS. Discussions, quizzes, and surveys can be done by using Kahoot. While using Kahoot, the teacher projects the questions to be asked on a big screen and the students answer these questions by the aid of using their smartphones, tablets or computers. What makes Kahoot a game-based student response system is that the teacher becomes the presenter of the game and the students compete to answer the questions in the fastest way with the music playing in the background (Wang, 2015). The students and the teachers can get instant feedback by using Kahoot and also the students can evaluate their understandings on time. Kahoot creates a more fun environment in the classroom and lets the students learn the topic more effectively in a competitive environment (Wang, 2015).

Socrative is another tool which has features like Kahoot's but non-game-based and widely-used. Socrative is a non-game-based SRS which is web-based like Kahoot and which does not require any special tools (Coca and Slisko, 2013). In Socrative, the answers of the students are evaluated, and feedback is given instantly.

When the studies in the literature are analyzed, it can be seen that most of these studies compare classes where SRSs is being used to the classes where there is no use of SRSs. Besides, To our knowledge, there are no studies that compare the game-based SRS and non-game-based SRS. Wang (2015) found that in a non-experimental study GSRSs increase the engagement of the students more compared to non-game based SRSs, but it is important to test this topic experimentally.

SRSs create an exam environment for the students. It is very important to determine how this exam environment affects the test anxiety of the students. When the studies of Mavridis and Tsiatsos (2016) are analyzed, it is seen that the students who are evaluated by using game-based assessment have a lower test anxiety compared to that of the students that are evaluated by using conventional methods. But, in the literature, there are no SRS studies with such results. Because of this, it is essential to analyze the use of GSRS and non-game-based SRS on the levels of test anxieties of students. Besides, when the studies in the literature are analyzed, it is seen that there are limited studies where SRSs are used in social studies lessons. This study is important also because of being done in the scope of social studies lessons.

Accordingly, the research questions examined were:

1. Are there any differences between the GSRS group and non-game-based SRS group concerning the students' achievement?

2. Are there any differences between the GSRS group and non-game-based SRS group concerning the students' engagement?

3. Are there any differences between the GSRS group and non-game-based SRS group concerning the students' test anxiety level? 


\section{Method}

This study uses quasi-experimental design which is one of the experimental designs of quantitative research approaches with the aim of finding out the effects of game-based and non-game based question-answer systems on the achievements, engagements and test anxieties of students. The aim of the quasi-experimental design is to determine the cause and effect relation. Random assignment of the samples is not a part of the quasiexperimental design (McMillan, Schumacher, 2014). Quasi-experimental design is chosen to be used in this study as this study does not assign the groups randomly.

\section{Study Group}

This study was conducted with 46 seventh grade students who received education in two different classes of a secondary school in Turkey during 2015-2016 education year. One of the classes was determined as the experiment group $(n=23)$ that apply game-based question and answer system named Kahoot, and the other class was determined as the control group $(\mathrm{n}=23)$ that apply non-game-based question and answer system called Socrative. The data related to the study group of this research are represented in Table 1.

\section{Data Collection Tools}

\section{Achievement Test}

In this study, a multiple choice achievement test was prepared which consists of the gains of the Living Democracy chapter of seventh grade Social Sciences course book to determine the effect of both game-based question and answers systems and non-game based question and answer systems on the achievements of the students. Opinions of experts were taken into consideration to determine if the questions are valid and suitable regarding the principles of assessment and evaluation. There are 25 questions on the achievement test. Before applying the test to seventh-grade students, the test was piloted

Table 1

Demographic Information related to the study group

\begin{tabular}{lccc}
\hline Groups & & Frequency & $\%$ \\
\hline Game-based SRS & Girl & 11 & 47,83 \\
& Boy & 12 & 52,17 \\
Non-game-based SRS & Girl & 9 & 39,13 \\
& Boy & 14 & 60,87 \\
\hline Total & & 46 & 100 \\
\hline
\end{tabular}


to 60 eighth-grade students for calculating the validity and confidence coefficient. As a result of the pilot test, the 20 questions with the highest coefficient out of 25 questions were chosen which resulted in the final version of the achievement test. The Kuder Richardson-20 (KR-20) value of the achievement test was calculated as 0.78 .

\section{Student Engagement Questionnaire}

This study uses Student Engagement Questionnaire which was created by Reeve and Tseng (2011) and adapted to Turkish by Eren (2013) by conducting the validity and reliability studies, to measure the attendance of students in the lessons. The scale consists of 22 items. The scale items are prepared in 7 Likert Scale which goes from "Totally disagree" (1 point) to "Totally agree." But in this study, the scale was used in 5 Likert Scale as a result of considering the opinions of the students. The Cronbach Alpha value of the scale was calculated as 0.88 for this study.

\section{Test Anxiety Scale}

Test anxiety scale was created by researchers by adapting the items in the text anxiety scales that were created by Spielberger (1980) and Sarason (1978). The items of test anxiety scale and information regarding where these items were taken are shown in Table 2. The items in the scale were firstly translated to Turkish and then checked by three English language experts and two instructional technology experts to ensure the validity and reliability of the scale. The pilot test was applied to 58 students in eighth grade after making the arrangements in the scale by taking the feedback of the experts into consideration. The Cronbach Alpha value of the scale was calculated as 0.78 after the pilot study.

Table 2

Test Anxiety Scale Items

Statement

- During electronic tests I get so nervous that I forget facts I really know.

- I feel my heart beating very fast during electronic tests.

- I worry a deal before taking electronic test.

- I feel very panicky when I take electronic test.

- During electronic test I feel very tense.

- I feel confident and relax while taking electronic tests

- During electronic tests, I find myself thinking of things unrelated to the actual course material.

- Even when I am well prepared for an electronic test, I feel very anxious about it.

- Before an electronic test, I find my hands or arms trembling.

- I get depressed after taking an electronic test.

- I would write a paper than take an electronic test for my mark in a course.

- While taking an Electronic test, I find myself thinking of how much brighter the other students are than I am.

\section{Source}

Spielberger (1980)

Sarason (1978) 


\section{Implementation Process}

In the study, teaching the Living Democracy section of the Social Sciences course book for 7th graders was done by applying the GSRS (Kahoot) to the experiment group and applying the non-GSRS (Socrative) to the control group for 4 weeks where each weak included 3 course periods as 3 course periods for the teacher to teach the topic and 1 course period for applying kahoot and socrative systems. The teacher's role was the same for two groups. The teacher gave a lecture to students and then applied the kahoot to the experiment group and applied the socrative to control group with the week's questions. The course content and related achievement test questions'numbers were given in Table 3 in detail. The same questions were asked in Kahoot and Socrative.

The researchers prepared 20 multiple choice questions to apply after the end of every sub-topic of the chapter both for Kahoot and for Socrative. Kahoot and Socrative were applied each week for four weeks at the end of the topic. The achievement test and engagement scale were applied as pre-test and post-test for the experiment and control groups whereas test anxiety scale was applied as post-test. During the implementation process, the technology classroom of the school was used to create an environment that gives the students the chance to do the activity individually (Fig. 1).

\section{Data Analysis}

The data were analyzed using SPSS 20.0. Data collected from the achievement test, student engagement questionnaire and test anxiety scale were analyzed using inferential

Table 3

Course Content and Objectives

\begin{tabular}{llll}
\hline Week & Topic of the week & Course Objectives & $\begin{array}{l}\text { Related Achievement } \\
\text { Test Questions } \\
\text { Numbers }\end{array}$ \\
\hline 1st Week & $\begin{array}{l}\text { Management under- } \\
\text { standing in Turkish } \\
\text { states }\end{array}$ & $\begin{array}{l}\text { Students realize the change and continuity in } \\
\text { the way of management and dominance in the } \\
\text { Turkish states in the historical process. }\end{array}$ & $1,2,6,13,14,11$ \\
2nd Week & $\begin{array}{l}\text { State qualifications } \\
\text { and management } \\
\text { structure }\end{array}$ & $\begin{array}{l}\text { Students analyze the management structure of } \\
\text { the Republic of Turkey within the framework of } \\
\text { legislative, executive and judicial concept. }\end{array}$ & $3,4,5,10,12,17$, \\
3rd Week & $\begin{array}{l}\text { Agenda-makers and } \\
\text { those influencing } \\
\text { management }\end{array}$ & $\begin{array}{l}\text { Students discuss how the political parties, non- } \\
\text { governmental organizations, the media and } \\
\text { the individual influence the decision-making } \\
\text { processes of the agenda and the administration. }\end{array}$ & $7,8,9$ \\
4th Week & $\begin{array}{l}\text { Democracy in Social } \\
\text { Clubs }\end{array}$ & $\begin{array}{l}\text { Students analyze the processes in educational } \\
\text { and social activities regarding the principles of } \\
\text { democracy. }\end{array}$ & $15,16,19$ \\
\hline
\end{tabular}




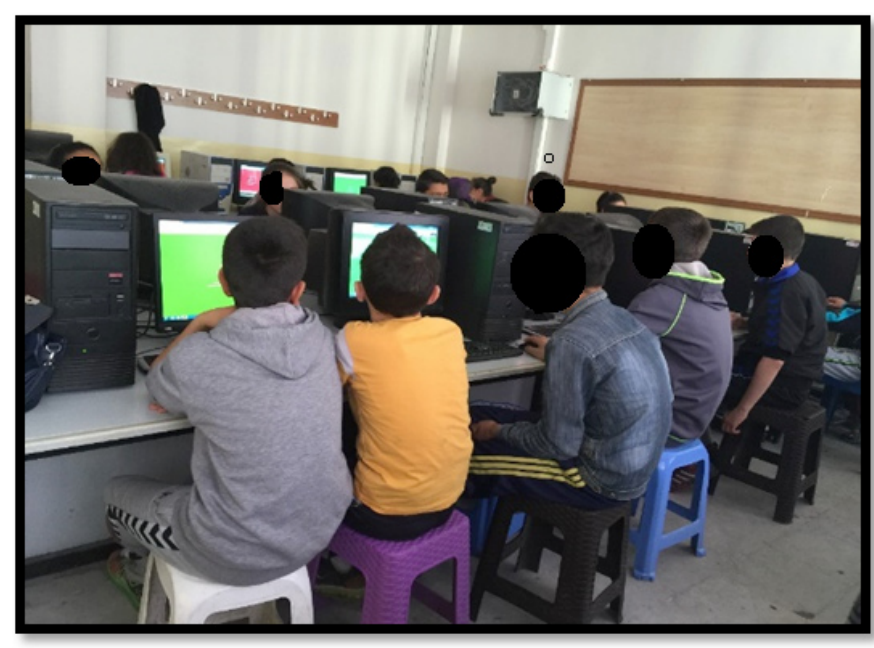

Fig. 1. Students using computers to access quizzes.

statistical analysis techniques. An independent samples t-test was used to reveal differences between groups concerning achievement, engagement, and test anxiety levels.

\section{Results}

\section{Are there any differences between the GSRS group and non-game-based SRS group concerning the students' achievement?}

To understand whether students' pre-test achievement test results had any significant difference between the two groups, an independent sample t-test was conducted. The results showed no significant difference between the two groups' pre-test scores $(\mathrm{t}(44)=.672, \mathrm{p}=.505>.05)$. An independent sample $\mathrm{t}$-test was used to determine whether there is a significant difference between the use of GSRSs and SRSs regarding achievement. For this purpose, the normality of data was controlled and it was seen that the data had a normal distribution. Table 4, the t-test results indicated a significant difference between the GSRS and SRS group; $(\mathrm{t}(44)=2.236, \mathrm{p}=.030<.05)$. The mean achievement score of the GSRS group $(\bar{X}=67.39)$ was higher than that of the nongame-based SRS group ( $\bar{X}=58.70)$.

Table 4

Independent sample t-test results for achievement scores of students

\begin{tabular}{lllllll}
\hline Group & $\mathrm{N}$ & $\bar{X}$ & $\mathrm{Sd}$ & $\mathrm{df}$ & $\mathrm{t}$ & $\mathrm{p}$ \\
\hline GSRS Group & 23 & 67.39 & 14.450 & 44 & 2.236 & .030 \\
SRS Group & 23 & 58.70 & 11.795 & & & \\
\hline
\end{tabular}


Table 5

Independent sample t-test results for engagement scores of students

\begin{tabular}{lllllll}
\hline Group & $\mathrm{N}$ & $\bar{X}$ & $\mathrm{Sd}$ & $\mathrm{df}$ & $\mathrm{t}$ & $\mathrm{p}$ \\
\hline GSRS Group & 23 & 4.130 & .555 & 44 & 2.283 & .028 \\
SRS Group & 23 & 3.762 & .512 & & & \\
\hline
\end{tabular}

Table 6

Independent samples t-test results for test anxiety scores of students

\begin{tabular}{lllllll}
\hline Group & $\mathrm{N}$ & $\bar{X}$ & $\mathrm{Sd}$ & $\mathrm{df}$ & $\mathrm{t}$ & $\mathrm{p}$ \\
\hline GSRS Group & 23 & 1.871 & .420 & 44 & 2.551 & .014 \\
SRS Group & 23 & 2.238 & .529 & & & \\
\hline
\end{tabular}

\section{Are there any differences between the GSRS group and non-game-based SRS group concerning the students' engagement?}

To understand whether students' pre-test engagement test results had any significant difference between the two groups, an independent sample t-test was conducted. The findings showed that there is no difference between experimental and control groups' pre-test scores $(\mathrm{t}(44)=.632, \mathrm{p}=.532>.05)$. An independent samples t-test was used to determine whether there was a significant difference between the control and experimental groups concerning engagement levels. For this purpose, the normality of data was controlled, and it was seen that the data had a normal distribution. As shown in Table 5, a significant difference was found $(\mathrm{t}(44)=2.283, \mathrm{p}=.028<.05)$ in post-test results: the GSRS group's engagement scores $(\bar{X}=4.130)$ were higher than those of the non-game SRS group $(\bar{X}=3.762)$.

\section{Are there any differences between the GSRS group and non-game-based SRS group concerning the student's test anxiety level?}

To understand whether students' test anxiety scale results had any significant difference between the two groups, an independent sample t-test was conducted. For this purpose, the normality of data was controlled, and it was seen that the data had a normal distribution. As shown in Table 6, a significant difference was found $(\mathrm{t}(44)=2.551$, $\mathrm{p}=.014<.05)$ : the GSRS group's test anxiety scores $(\bar{X}=1.871)$ were lower than those of the non-game SRS group ( $\bar{X}=2.238$ ).

\section{Discussion}

In this study, the effect of using GSRS and non-game-based SRS on the achievement, engagement, and test anxiety levels of secondary school students in social sci- 
ences course was researched. As a result of the study, it is found out that the group of students that use GSRS has a greater level of achievement compared to the group of students that use non-game-based SRS. In the literature, there are no studies that compare game-based and non-game-based SRSs. In spite of this, one study in the literature reveals that game-based assessment increases achievement more compared to traditional assessment (Mavridis and Tsiatsos, 2016). Besides, Wang (2008) concluded that the students become more successful in game-based assessment compared to web-based test and traditional assessment which is also defined as paper and pencil test. The higher success levels of the students with GSRS can be explained by using the higher levels of immersion of the students in the GSRS group. In this direction, the study of Chang, Wu, Weng and Sung (2012) reveals that game-based learning approach increases flow experience levels more compared to traditional instruction. Additively, Schüler (2007) states that flow experience is a significant predictor of exam performance.

It was found out as a result of the study that the engagement level in the group that uses GSRS is higher compared to that of the group using non-game SRS. Parallel to that finding, Wang (2015) states that GSRSs increases engagement levels of the students. Coming up with this result can be explained by saying that using GSRSs creates a game environment and catches the attention of the students more. In this direction, there are findings in the literature related to the engagement-increasing effect of the games (Annetta, Minogue, Holmes, Cheng, 2009; Boyle, Connolly, Hainey, Boyle, 2012; Schwabe and Göth, 2005).

Besides, it was found at the end of the study that the anxiety levels of the students in the group that uses GSRS are lower compared to the group of non-game SRS users. This finding is consistent with the results from previous studies about game-based assessment (Kocadere and Çağlar, 2015; Mavridis and Tsiatsos, 2016; Smits and Charlier, 2011). There may be various reasons for the low levels of test anxiety in the GSRS group. In this direction, the engaging and motivating side of the game environment (Oblinger, 2004) can be shown as one reason for this issue. Additively, Jennett et al. (2008) states that engagement levels can affect anxiety. In this study too, it was found that the use of GSRS increases engagement levels. Besides, in this study, the high achievement levels of GSRS group can be linked to the low levels of test anxiety. In this direction, the findings in the literature state that there is a negative correlation between achievement and test anxiety (Cassady and Johnson, 2002; Falaye, 2010). One of the reasons for the low levels of test anxiety in the GSRS group can be explained by the increasing low experience levels with the game-based assessment. In this direction, Kocadere and Çağlar (2015) state that the students to whom the game-based assessment is applied have flow experience and this issue decreases test anxiety.

This study has the potential to become a source of inspiration and an example for the further studies. Moreover, it is very important that there are no studies in the literature where GSRSs and non-game-based SRSs are compared. GSRS may not be very suitable for every occasion and group, but this study came up with quite positive results for secondary school students in the scope of social sciences course. 


\section{Limitations and Suggestions}

This study is limited by its relatively small sample. The future studies may use a greater sample group. Besides, the opinions of the students are not analyzed by using a qualitative method. Because of this, the future studies can make a deeper analysis by using a qualitative method. Additively, this study considers the achievements of the students but does not take the retention of the information into consideration. As a result of this, the future studies can make a research about the retention of information that is gathered by using GSRS.

\section{References}

Adesope, O.O., Nesbit, J.C. (2013). Learning with animated and static concept maps. Learning and Instruction, 27, 1-10.

Aljaloud, A., Gromik, N., Billingsley, W., Kwan, P. (2015). Research trends in student response systems: a literature review. International Journal of Learning Technology, 10(4), 313-325.

Annetta, L.A., Minogue, J., Holmes, S.Y., Cheng, M.T. (2009). Investigating the impact of video games on high school students' engagement and learning about genetics. Computers and Education, 53(1), 74-85.

Bergtrom, G. (2006). Clicker sets as learning objects. Interdisciplinary Journal of Knowledge and Learning Objects, 2, 105-110.

Bessler, W.C., Nisbet, J.J. (1971). The use of an electronic response system in teaching biology. Science Education, 55(3), 275-284.

Burns, R.A. (1985). Information impact and factors affecting recall. Paper presented at Annual National Conference on Teaching Excellence and Conference of Administrators, Austin, TX.

Boyle, E.A., Connolly, T.M., Hainey, T., Boyle, J.M. (2012). Engagement in digital entertainment games: A systematic review. Computers in Human Behavior, 28(3), 771-780.

Caldwell, J.E. (2007). Clickers in the large classroom: current research and best-practice tips. CBE-Life Sciences Education, 6(1), 9-20.

Cassady, J.C., Johnson, R.E. (2002). Cognitive test anxiety and academic performance. Contemporary Educational Psychology, 27, 270-295.

Chang, K.E., Wu, L.J., Weng, S.E., Sung, Y.T. (2012). Embedding game-based problem-solving phase into problem-posing system for mathematics learning. Computers \& Education, 58(2), 775-786.

Coca, D.M., Slisko, J. (2013). Software socrative and smartphones as tools for implementation of basic processes of active physics learning in classroom: an initial feasibility study with prospective teachers. European Journal of Physics Education, 4(2), 17-24.

Duncan, D. (2005). Clickers in the Classroom: How to Enhance Science Teaching Using Classroom Response Systems. New York: Addison Wesley and Benjamin Cummings.

Eren, A. (2013). Prospective teachers' perceptions of instrumentality, boredom coping strategies, \& four aspects of engagement. Teaching Education, 24(3), 302-326.

Falaye, B. A. (2010). Cognitive test anxiety and learning outcomes of selected undergraduate students. The African Symposium. 10(2), 69-74.

Fies, C., Marshall, J. (2006). Classroom response systems: a review of the literatüre. Journal of Science Education and Technology, 15(1), 100-109.

Habel, C., Stubbs, M. (2014). Mobile phone voting for participation and engagement in a large compulsory law course. Research in Learning Technology, 22, 1-15. 
Hunsu, N.J., Adesope, O., Bayly, D.J. (2016). A meta-analysis of the effects of audience response systems (clicker-based technologies) on cognition and affect. Computers \& Education, 94, 102-119.

Jennett, C., Cox, A.L., Cairns, P., Dhoparaee, S., Epps, A., Tijs, T., Walton, A. (2008). Measuring and defining the experience of immersion in games. International Journal of Human-Computer Studies, 66, 641-661.

Johnson, K., Lillis, C. (2010). Clickers in the laboratory: student thoughts and views. Interdisciplinary Journal of Information, Knowledge and Management, 5, 139-151.

Jones, S., Henderson, D., Sealover, P. (2009). "Clickers" in the classroom. Teaching and Learning in Nursing, $4(1), 2-5$.

Judson, E., Sawada, D. (2002). Learning from past and present: electronic response systems in college lecture halls. Journal of Computers in Mathematics and Science Teaching, 21(2), 167-181.

Kocadere, S.A., Çağlar, S. (2015). The design and implementation of a gamified assessment. Journal of eLearning and Knowledge Society, 11(3), 85-99.

Kortemeyer, G. (2016). The psychometric properties of classroom response system data: a case study. Journal of Science Education and Technology, 25(4), 561-574.

Mavridis, A. Tsiatsos, T. (2016). Game-based assessment: investigating the impact on test anxiety and exam performance. Journal of Computer Assisted Learning, 33(2), 1-14. https://doi.org/10.1111/jcal.12170

McMillan, J.H., Schumacher, S. (2014). Research in Education: Evidence-Based Inquiry (7th Edition). London: Pearson.

Morling, B., McAuliffe, M., Cohen, L., DiLorenzo, T.M. (2008). Efficacy of personal response systems (“clickers") in large, introductory psychology classes. Teaching of Psychology, 35, 45-50.

Mula, J.M., Kavanagh, M. (2009). Click go the students, click-click-click: the efficacy of a student response system for engaging students to improve feedback and performance. E-Journal of Business Education and Scholarship of Teaching, 3(1), 1-17.

Oblinger, D. (2004). The next generation of educational engagement. Journal of Interactive Media in Education, 8, 1-18.

Pettit, R.K., McCoy, L., Kinney, M., Schwartz, F.N. (2015). Student perceptions of gamified audience response system interactions in large group lectures and via lecture capture technology. BMC Medical Education, $15(1), 92$.

Poirier, C.R., Feldman, S.R. (2007). Promoting active learning using individual response technology in large introductory psychology classes. Teaching of Psychology, 34(3), 194-196.

Reeve, J., Tseng, C.-M. (2011). Agency as a fourth aspect of students' engagement during learning activities. Contemporary Educational Psychology, 36, 257-267.

Richardson, A.M., Dunn, P.K., McDonald, C., Oprescu, F. (2015). Crisp: an instrument for assessing student perceptions of classroom response systems. Journal of Science Education and Technology, 24(4), $432-447$.

Roedriger, H.L., Karpicke, J.D. (2006). The power of testing memory: basic research and implications for educational practice. Perspectives in Psychological Science, 1(3), 181-210.

Sarason, I.G. (1978). The test anxiety scale: concept and research. In: C.D. Spielberger I.G. Sarason (Eds.), Stress and Anxiety (Vol. 5). Washington, D.C.: Hemisphere Publishing Corp, 193-216.

Schüler, J. (2007). Arousal of flow-experience in a learning setting and its effects on exam-performance and affect. Zeitschrift für Padagogische Psychologie, 21, 217-227.

Schwabe, G., Göth, C. (2005). Mobile learning with a mobile game: design and motivational effects. Journal of Computer Assisted Learning, 21(3), 204-216.

Simpson, V., Oliver, M. (2007). Electronic voting systems for lectures then and now: a comparison of research and practice. Australasian Journal of Educational Technology, 23(2), 187-208.

Smits, J., Charlier, N. (2011). Game-based assessment and the effect on test anxiety: a case study. In European Conference on Game Based Learning (p.562). Academic Conferences International Limited.

Song, D., Oh, E.Y., Glazewski, K. (2017). Student-generated questioning activity in second language courses using a customized personal response system: a case study. Educational Technology Research and Development. https://doi.org/10.1007/s11423-017-9520-7.

Spielberger, C.D. (1980). Preliminary Professional Manual for the Test Anxiety Inventory. Palo Alto, CA: Consulting Psychologists Press.

Wang, A.I. (2015). The wear out effect of a game-based student response system. Computers \& Education, $82,217-227$.

Wang, T.H. (2008). Web-based quiz-game-like formative assessment: development and evaluation. Computers \& Education, 51, 1247-1263. 
Z. Turan is an Assistant Professor at the Department of Computer Education \& Instructional Technology at Ataturk University in TURKEY. Her research interests are in the computer-based instruction, social media, instructional design, and research methods.

E. Meral is currently a Research Assistant at the Department of Social Sciences Education at Ataturk University in TURKEY. Her research interests are computer-based social sciences education. 